\title{
Body Mass Index or Waist Circumference: Which Is the Better Predictor for Hypertension and Dyslipidemia in Overweight/Obese Children and Adolescents? Association of Cardiovascular Risk Related to Body Mass Index or Waist Circumference
}

\author{
Dagmar Gröber-Grätz ${ }^{a} \quad$ Kurt Widhalm ${ }^{g} \quad$ Martina de Zwaan ${ }^{b} \quad$ Thomas Reinehr $^{c}$ \\ Susann Blüher ${ }^{d}$ Karl Otfried Schwabe Susanna Wiegand ${ }^{f}$ Reinhard W. Holla \\ on behalf of the APV Study Group and the German BMBF Competence \\ Network Obesity \\ ${ }^{\mathrm{a}}$ Institute of Epidemiology and Medical Biometry, University of Ulm, Ulm, ${ }^{\mathrm{b}}$ Department of Psychosomatic Medicine and \\ Psychotherapy, Hannover Medical School, Hannover, 'Vestische Kinderklinik Datteln, Institute of Pediatric Nutrition \\ Medicine, University of Witten-Herdecke, Datteln, ${ }^{\mathrm{d} H o s p i t a l}$ for Children and Adolescents, University of Leipzig, Leipzig, \\ ${ }^{e}$ Centre for Paediatric and Adolescent Medicine, University of Freiburg, Freiburg, and ${ }^{f}$ Children's Hospital, Department of \\ Pediatric Endocrinology, Charité Berlin, Berlin, Germany; ${ }^{9}$ Division of Clinical Nutrition and Prevention, Department of \\ Pediatrics, University of Vienna, Vienna, Austria
}

\section{Key Words}

Body mass index · Dyslipidemia $\cdot$ Hypertension · Obesity $\cdot$ Waist circumference

\footnotetext{
Abstract

Background: In order to assess the relationship between hypertension or dyslipidemia and obesity, the body mass index (BMI) is usually used. Unlike waist circumference (WC), BMI does not reflect body fat distribution. The aim of this study is to investigate whether BMI or WC is a better predictor of hypertension or dyslipidemia in overweight/obese children and adolescents. Methods: As of November 2012, the APV database contained data on 81,819 patients from 189 specialized pediatric obesity institutions in Germany, Austria and Switzerland. Logistic regression analysis was conducted using odds ratios (OR) with $95 \% \mathrm{Cl}$. Results: The average age
}

of the youths $(n=5.978)$ was $13.9 \pm 1.8$ years. Mean BMI-SDS was $2.0 \pm 0.5$, and mean WC-SDS was $2.2 \pm 0.5$. Both BMI-SDS and WC-SDS are significant predictors of hypertension and dyslipidemia: BMI-SDS is a better predictor $(O R=2.60)$ for hypertension than WC-SDS (OR $=1.85)$, while WC-SDS (OR = $1.90)$ was slightly superior to BMI-SDS $(O R=1.86)$ in predicting adverse lipid profiles. Compared to normal-weight patients, obese patients (BMI $\geq 97$ th percentile) exhibited increased systolic ( $+6.3 \mathrm{~mm} \mathrm{Hg}$ ) and diastolic blood pressure $(+3.9 \mathrm{~mm} \mathrm{Hg})$. However, this difference was only $+4.8 \mathrm{~mm}$ $\mathrm{Hg}$ (systolic) and $+2.6 \mathrm{~mm} \mathrm{Hg}$ (diastolic) if WC >97th percentile was used. Conclusion: BMI-SDS is more closely associated with hypertension, while WC-SDS is more closely associated with dyslipidemia. However, the additional measurement of WC has only a small benefit in obese youths.

Copyright $\odot 2013$ S. Karger AG, Basel

\section{KARGER}

E-Mail karger@karger.com

www.karger.com/hrp
(C) 2013 S. Karger AG, Basel

$1663-2818 / 13 / 0803-0170 \$ 38.00 / 0$
Dr. biol. hum. Dagmar Gröber-Grätz MPH

C/o Prof. Dr. med. Reinhard Holl

ZIBMT/Institute of Epidemiology and Medical Biometry, University of Ulm

Albert-Einstein-Allee 41, DE-89081 Ulm (Germany)

E-Mail reinhard.holl@uni-ulm.de 


\section{Introduction}

Prevalence and severity of obesity have increased in childhood and adolescence during the last decades $[1,2]$. However, a recent study reported stable or declining prevalence [3]. Obesity is a major risk factor for many chronic diseases and can lead to metabolic (dyslipidemia, diabetes mellitus type 2), cardiovascular and orthopedic diseases, as well as an increased cancer risk [4]. An obese child is at risk of becoming an obese adult with a high rate of severe comorbidities and premature death. It is known that the degree of obesity correlates with hypertension, carotid intima-media thickness and left ventricular hypertrophy $[5,6]$. We recently reported that elevated blood pressure is the most prevalent risk factor in children and adolescents and exhibits the strongest association with body mass index (BMI) [7]. In addition, the prevalences of diabetes, dyslipidemia and metabolic syndrome increase with increasing BMI [8].

BMI determines the severity of obesity, but not the distribution of body fat. Adipose tissue is a dynamic endocrine organ secreting several inflammatory proteins that increase the risk of cardiovascular disease (CVD) [9]. Some studies indicate that body fat on hips and thighs is less detrimental to health than fat accumulating around the waist [10]. Metabolic and cardiovascular complications are closely associated with an increase in visceral fat for which waist circumference (WC) is an indicator [11].

Several studies have examined the predictive value of BMI and WC for hypertension, CVD and diabetes mellitus type 2. The Emerging Risk Factors Collaboration found in adults that BMI and WC, either alone or in combination, do not improve the prediction of CVD risk when additional information on systolic blood pressure, history of diabetes and lipids are available [12]. In contrast, Yusuf et al. [13] found in an international standardized case-control study of adults that waist- and hip circumference had a highly significant association with myocardial infarction.

Few studies in pediatric populations have reported contradictory findings for both measurements and their associations with comorbidities. An Australian study of adolescents by Denney-Wilson et al. [10] assessed the association between BMI, WC, risk factors for heart disease, type 2 diabetes and fatty liver disease. They found that WC is not a better predictor of metabolic risk than BMI. Results of a systematic review also found no evidence to support the assumption that WC is superior to BMI for the prediction of an adverse CVD risk profile, including blood pressure, in children [14]. However, Lee et al. [15] reported in a small study with 167 youths that obesityrelated health risk assessment can be improved by considering WC in addition to BMI percentiles. They concluded that WC should be included together with BMI in the evaluation of obesity in children to identify those at increased health risk. Recently, Bekkers et al. [16] reported that a high BMI and large WC were associated with higher blood pressure levels and adverse cholesterol concentrations.

The aim of this study was to investigate whether BMI, $\mathrm{WC}$ or their combination is a better predictor for hypertension and dyslipidemia in a large multicenter survey of obese youths. We will also assess whether BMI and WC have the same predictive value for boys and girls.

\section{Methods}

Based on the German guidelines for diagnosis and treatment of overweight children and adolescents (www.a-g-a.de), computer software was developed for standardized, prospective documentation of anthropometric and metabolic parameters in overweight children and adolescents (APV, www.a-p-v.de). Twice a year, participating centers (inpatient rehabilitation or outpatient), specialized in obesity care for children and adolescents, transmit anonymized data to the University of Ulm for central analysis. Data are checked for completeness and plausibility. Implausible data are reported back twice yearly to the centers for correction. The APV database is used for clinical research, quality assurance, benchmarking and numerous evaluations in order to improve treatment, rehabilitation and prevention of overweight and obesity.

As of November 2012, the APV database contained data on 81,819 patients from 189 centers (28 inpatient rehabilitation and 161 outpatient) in Germany, Austria and Switzerland. The inclusion criterion for this analysis was an age between 11 and 17.9 years. The restriction to this age range was chosen because in the German Health Interview and Examination Survey for Children and Adolescents (KiGGS) survey [17] measurements for WC were documented in this age group only. In order to achieve ethnic homogeneity of the study population, patients with a migration background were excluded from this analysis [18]. Youths using antihypertensive or lipid-lowering medications were also excluded.

Age- and gender-specific percentiles for children and adolescents were used for BMI [19] and WC [17] based on KiGGS. KiGGS data was chosen since reference data for both BMI and WC measurements were available. WC was measured at the narrowest point below the ribs or halfway between the lowest ribs and the highest point of the iliac crest. Hypertension was also evaluated based on German KiGGS reference data [20]. Hypertension was diagnosed if either systolic or diastolic blood pressure was elevated above the 95th percentile for age and gender, at more than $50 \%$ of individual blood pressure measurements. Examination and anthropometric parameters are documented routinely in specialized obesity centers according to the standardized specifications of AGA (www.a-g-a.de). Dyslipidemia was defined as at least one abnormal value for cholesterol, high-density lipoprotein cholesterol (HDL), low-density lipoprotein cholesterol (LDL) or triglycerides, 
Table 1. Classification of the cohort in weight categories based on $\mathrm{BMI}$ and $\mathrm{WC}$ according to the KiGGS percentiles

\begin{tabular}{lllll}
\hline & $\begin{array}{l}\text { <90th } \\
\text { percentile }\end{array}$ & $\begin{array}{l}\text { 90-97th } \\
\text { percentile }\end{array}$ & $\begin{array}{l}\text { 97-99.5th } \\
\text { percentile }\end{array}$ & $\begin{array}{l}>99.5 \text { th } \\
\text { percentile }\end{array}$ \\
\hline BMI all & $6.3 / 374$ & $33.2 / 1,982$ & $49.8 / 2,974$ & $10.8 / 648$ \\
BMI boys & $5.9 / 166$ & $30.8 / 862$ & $51.2 / 1,433$ & $12.1 / 336$ \\
BMI girls & $6.5 / 208$ & $35.2 / 1,120$ & $48.4 / 1,541$ & $9.8 / 312$ \\
\hline WC all & $4.0 / 236$ & $17.3 / 1,032$ & $55.4 / 3,311$ & $23.4 / 1,399$ \\
WC boys & $3.7 / 102$ & $17.6 / 493$ & $52.1 / 1,458$ & $26.6 / 744$ \\
WC girls & $4.2 / 134$ & $16.9 / 539$ & $58.3 / 1,853$ & $20.6 / 655$ \\
\hline
\end{tabular}

Values are given as $\% / \mathrm{n}$.

based on the guidelines of the American Heart Association [21]. Cutoff levels were total cholesterol $>200 \mathrm{mg} / \mathrm{dl}$, HDL $<35 \mathrm{mg} / \mathrm{dl}$, $\mathrm{LDL}>130 \mathrm{mg} / \mathrm{dl}$ and triglycerides $>150 \mathrm{mg} / \mathrm{dl}$.

\section{Statistical Analysis}

All analyses were performed using SAS version 9.3 statistical software (SAS Institute Inc., Cary, N.C., USA). Values of $\mathrm{p}<0.05$ were regarded as significant. Continuous variables are given as means $\pm \mathrm{SD}$, and group differences were analyzed using a Wilcoxon test. Binary variables are presented as percentages, and group differences were analyzed using $\chi^{2}$ tests. Values of $p$ were corrected for multiple comparisons using the Holm method [22]. Correlations between BMI-SDS, WC-SDS and hypertension or dyslipidemia were tested using Spearman's rank correlation coefficient.

A logistic regression analysis was conducted to establish whether BMI-SDS or WC-SDS (the independent variable) is more predictive for hypertension or dyslipidemia (the dependent variable). Results are reported as odds ratios (OR) and 95\% CI based on maximum-likelihood estimation. The area under the curve (AUC) was used to assess the effectiveness for both measurements to predict comorbidities. An AUC of 0.5 means that the test is no better than mere chance; values $>0.5$ are more predictive.

To evaluate the increase in risk for hypertension and dyslipidemia with elevated BMI and WC, the children were divided into two groups each, i.e. BMI or WC $<97$ th percentile or $\geq 97$ th percentile according to age and gender. Logistic regression models with least square means were computed to quantify adjusted rates of hypertension or dyslipidemia for nonobese and obese patients.

\section{Results}

Data on BMI, WC, blood pressure and lipids were available for 5,978 adolescents 11-17.9 years of age (average: $13.8 \pm 1.8)$. There were fewer boys $(46.8 \%)$ than girls (53.2\%). The mean BMI-SDS was $2.0 \pm 0.5$ and the average WC-SDS was $2.2 \pm 0.5$. Table 1 lists the weight categories for $\mathrm{BMI}$ and $\mathrm{WC}$.
$42.4 \%$ of the population had hypertension and $33.0 \%$ had one or more abnormal lipid value. Girls were more likely to have hypertension than boys $(\mathrm{p}=0.04)$. Boys had a higher percentage of abnormal lipid levels $(\mathrm{p}=0.001)$. $50.7 \%$ of the children had either hypertension or dyslipidemia. The characteristics of the population are presented in table 2 .

\section{Correlation between BMI-SDS and WC-SDS}

BMI-SDS and WC-SDS correlated closely $(r=0.74$; $\mathrm{p}<0.0001)$. In the boys this correlation between BMISDS and WC-SDS was $\mathrm{r}=0.77(\mathrm{p}<0.0001)$, and in the girls it was $r=0.71(\mathrm{p}<0.0001)$.

Descriptive characteristics of youths with blood pressure $<97$ th percentile or $\geq 97$ th percentile as well as youths with and without dyslipidemia are presented in table 3.

Compared to nonobese (BMI $<97$ th percentile) subjects, systolic blood pressure was increased by $+6.3 \mathrm{~mm} \mathrm{Hg}$ and diastolic blood pressure by $+3.9 \mathrm{~mm} \mathrm{Hg}$ in obese patients (BMI $\geq 97$ th percentile). For patients with a $\mathrm{WC} \geq 97$ th percentile, increases of systolic blood pressure of $+4.9 \mathrm{~mm}$ $\mathrm{Hg}$ and diastolic blood pressure of $+2.6 \mathrm{~mm} \mathrm{Hg}$ were registered. Compared to subjects with a WC $<97$ th percentile, youths with a WC $\geq 97$ th percentile had higher cholesterol and triglyceride values, but lower HDL values. After stratifying by sex, girls with a BMI $\geq 97$ th percentile showed higher systolic blood pressure and LDL values compared to boys. Boys with a WC $\geq 97$ th percentile showed higher systolic blood pressure values compared to girls. The differences between the girls and boys are shown in table 4 .

Both BMI-SDS and WC-SDS were significant predictors of hypertension and dyslipidemia. BMI-SDS turned out to be a better predictor $(\mathrm{OR}=2.60)$ for hypertension than WC-SDS (OR = 1.85). This difference was similar for boys and girls. WC-SDS was a slightly better predictor $(\mathrm{OR}=$ $1.90)$ for dyslipidemia than BMI-SDS $(O R=1.86)$. The differences between the boys and girls are listed in table 5 .

Based on logistic regression analysis, the AUC confirmed that BMI-SDS was a better predictor $(\mathrm{AUC}=0.62)$ for hypertension than WC-SDS (AUC $=0.58 ; \mathrm{p}<0.0001$ ). There were no differences between BMI-SDS (AUC = 0.58 ) and WC-SDS (AUC $=0.58 ; \mathrm{p}=0.87$ ) for dyslipidemia. Combining the two measurements increased the prediction probability for both comorbidities only marginally, resulting in an AUC of 0.62 for hypertension and an AUC of 0.59 for dyslipidemia (fig. 1). For the prediction of hypertension, there was only a small difference between sexes (fig. 2). 
Table 2. Characteristics of study population and p values for differences between boys and girls (adjusted for multiple comparisons)

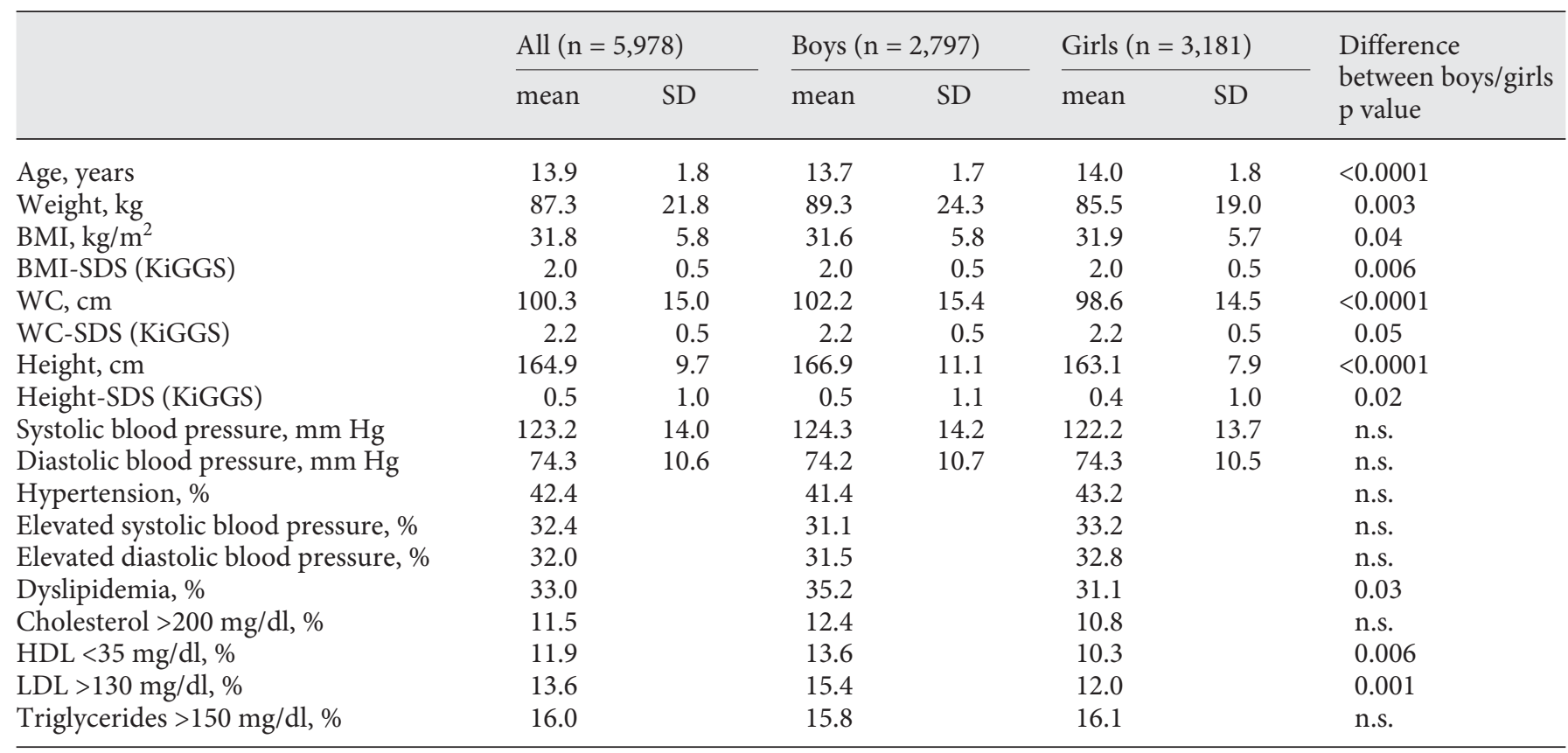

Table 3. Comparison between blood pressure $<97$ th percentile and hypertension $\geq 97$ th percentile and children with and without dyslipidemia (mean $\pm \mathrm{SD})$

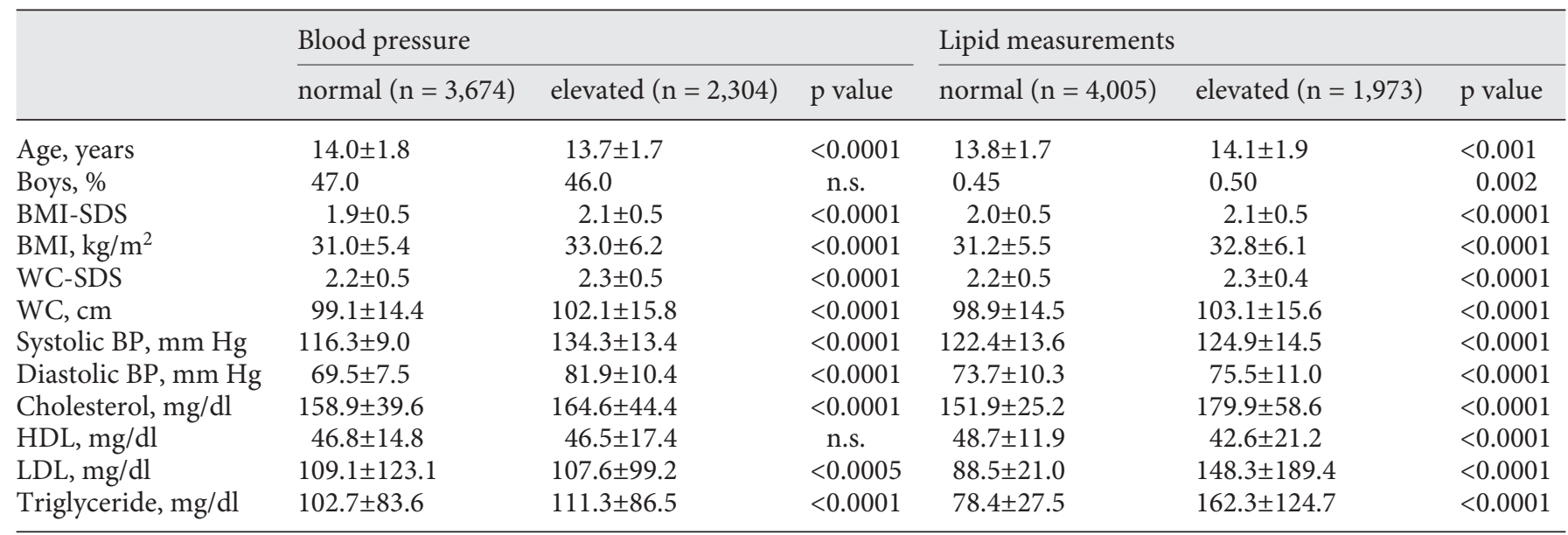

$\mathrm{BP}=$ Blood pressure.

\section{Discussion}

In the present study we compared BMI and WC with respect to their association with cardiovascular risk factors. Our results demonstrated that both BMI-SDS and WC-SDS were significant predictors of hypertension and dyslipidemia. We could detect that BMI-SDS is a better predictor for hypertension compared to WC-SDS. After stratifying by sex, BMI-SDS had a closer relation with hypertension in girls. On the other hand, WC-SDS showed a closer association with dyslipidemia in boys. Combining BMI and WC had only a small additional benefit for the prediction of either comorbidity. 
Table 4. Comparison of systolic/diastolic blood pressure and lipid profiles between non-obese patients (BMI/WC $<97$ th percentile) and obese (BMI/WC $\geq 97$ th percentile) patients adjusted for age, sex and height

\begin{tabular}{|c|c|c|c|c|c|c|}
\hline & \multicolumn{2}{|c|}{ All ( $\geq 97$ th percentile) } & \multicolumn{2}{|c|}{ Boys ( $\geq 97$ th percentile) } & \multicolumn{2}{|c|}{ Girls ( $\geq 97$ th percentile) } \\
\hline \multicolumn{7}{|l|}{ BMI } \\
\hline Patients, $\mathrm{n}$ & 2,998 & & 1,411 & & 1,587 & \\
\hline Diastolic BP, mm Hg & +3.9 & $\mathrm{p}<0.0001$ & +3.9 & $\mathrm{p}<0.0001$ & +3.8 & $\mathrm{p}<0.0001$ \\
\hline Cholesterol, mg/dl & -0.2 & $\mathrm{p}=0.83$ & +0.7 & $\mathrm{p}=0.69$ & -0.8 & $\mathrm{p}=0.55$ \\
\hline $\mathrm{HDL}, \mathrm{mg} / \mathrm{dl}$ & -4.0 & $\mathrm{p}<0.0001$ & -3.8 & $\mathrm{p}<0.0001$ & +4.0 & $\mathrm{p}<0.0001$ \\
\hline Triglyceride, mg/dl & +15.2 & $\mathrm{p}<0.0001$ & +15.6 & $\mathrm{p}<0.0001$ & +14.8 & $\mathrm{p}<0.0001$ \\
\hline \multicolumn{7}{|l|}{$W C$} \\
\hline Patients, $\mathrm{n}$ & 4,710 & & 2,202 & & 2,508 & \\
\hline Systolic BP, mm Hg & +4.3 & $\mathrm{p}<0.0001$ & +4.8 & $\mathrm{p}<0.0001$ & +3.8 & $\mathrm{p}<0.0001$ \\
\hline Diastolic BP, mm Hg & +2.4 & $\mathrm{p}<0.0001$ & +2.5 & $\mathrm{p}<0.0001$ & +2.2 & $\mathrm{p}<0.0001$ \\
\hline Cholesterol, mg/dl & +2.5 & $\mathrm{p}=0.06$ & +5.6 & $\mathrm{p}=0.007$ & +0.1 & $\mathrm{p}=0.94$ \\
\hline
\end{tabular}

$\mathrm{BP}=$ Blood pressure.

Table 5. Effect of BMI-SDS and WC-SDS in logistic regression as predictors for hypertension and dyslipidemia

\begin{tabular}{|c|c|c|c|c|c|c|c|}
\hline \multicolumn{8}{|c|}{ Elevated systolic BP } \\
\hline BMI-SDS & 2.74 & $2.40-3.13$ & 2.54 & $2.10-3.09$ & 2.92 & $2.44-3.52$ & 0.001 \\
\hline WC-SDS & 2.02 & $1.76-2.31$ & 2.14 & $1.76-2.60$ & 1.91 & $1.59-2.31$ & 0.003 \\
\hline \multicolumn{8}{|c|}{ Elevated diastolic BP } \\
\hline WC-SDS & 1.66 & $1.46-1.90$ & 1.84 & $1.53-2.23$ & 1.51 & $1.26-1.81$ & 0.026 \\
\hline \multicolumn{8}{|l|}{ Low HDL } \\
\hline BMI-SDS & 3.57 & $2.97-4.30$ & 3.84 & $2.30-4.97$ & 3.27 & $2.50-4.30$ & 0.002 \\
\hline WC-SDS & 4.29 & $3.48-5.32$ & 5.10 & $3.85-6.81$ & 3.42 & $2.50-4.72$ & 0.005 \\
\hline \multicolumn{8}{|c|}{ Elevated triglyceride } \\
\hline BMI-SDS & 1.80 & $1.54-2.10$ & 2.24 & $1.79-2.81$ & 1.48 & $1.20-1.83$ & 0.42 \\
\hline
\end{tabular}

$\mathrm{p}$ value differences between boys and girls. $\mathrm{BP}=\mathrm{Blood}$ pressure.

These results concur with previous findings from the APV study with 26,008 overweight and obese children and adolescents. The study found that the degree of overweight is strongly associated with decreased HDL-cholesterol. Obesity leads to increased triglycerides, high blood pressure and impaired glucose metabolism [8]. Similar findings were reported by the Kiel Obesity Prevention
Study. The authors compared associations of BMI, triceps skinfold, WC and percent fat mass with blood pressure and blood lipids in children and adolescents. They concluded that both BMI and WC are appropriate to estimate CVD risk [23]. In contrast, Meng et al. [24], who examined 1,452 school-age children between 7 and 17 years in Beijing found that WC showed a significantly 
Fig. 1. AUC with SD for BMI-SDS, WC-SDS and the combination of BMI-SDS and WC-SDS as predictors for hypertension and dyslipidemia.

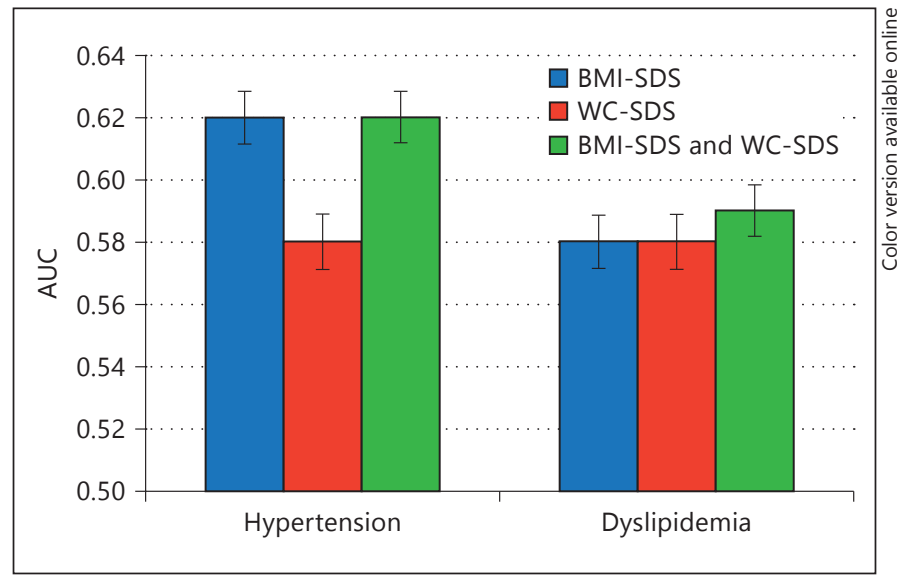

Fig. 2. AUC with SD for BMI-SDS, WCSDS and the combination of BMI-SDS and WC-SDS as predictors for hypertension and dyslipidemia separately for boys and girls.

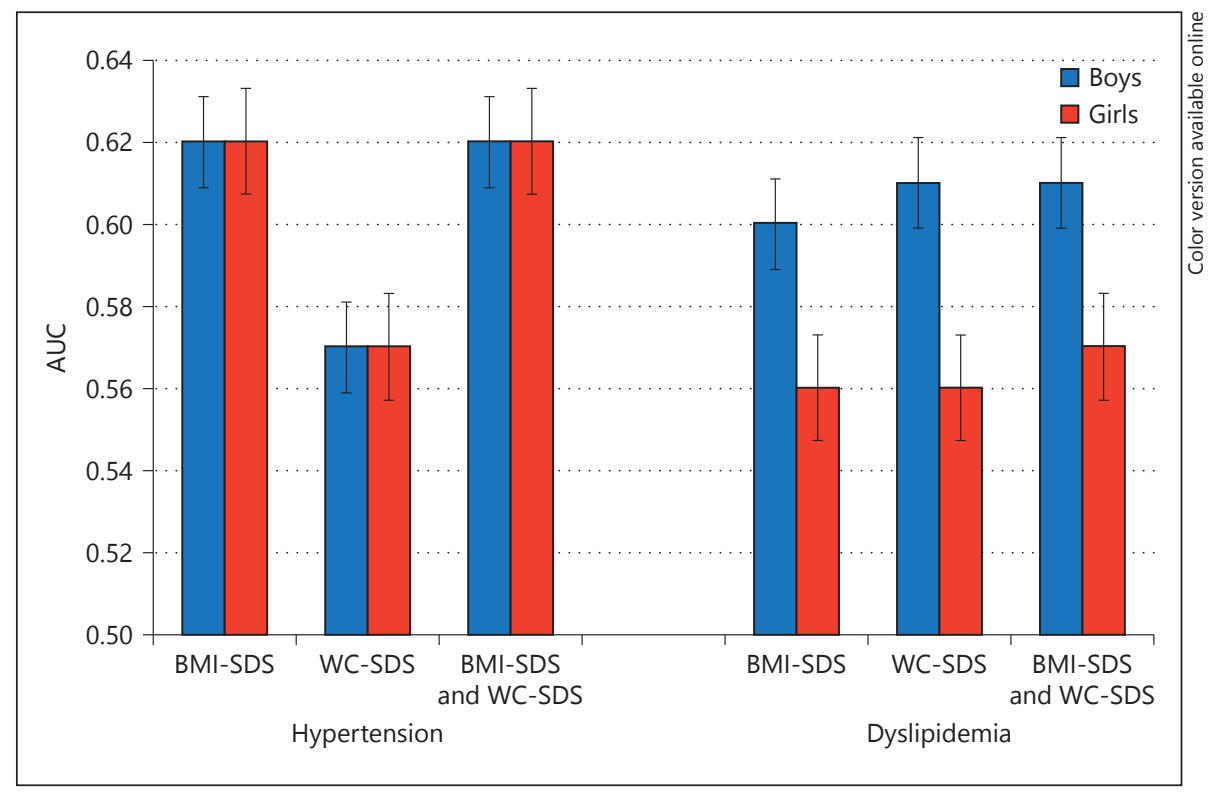

stronger relationship with dyslipidemia and fatty liver than BMI.

WC reflects abdominal fat and visceral tissue $[25,26]$, which seems to be a good predictor of metabolic syndrome in children [27]. Multiple screening tools are available to identify the body fat distribution in children. Computed tomography (CT), magnetic resonance imaging (MRI) and dual-energy X-ray absorptiometry (DXA) are accurate techniques for assessing central fat distribution [28]. However, their high cost and the radiation exposure (CT, DXA) make them unsuitable for children and large-scale studies [26]. Bioelectrical impedance analysis (BIA) is a common method for rapid and noninvasive quantification of body fat. Variations in body fat distribution, including the relationship between subcutaneous and intra-abdominal fat, can be assessed. Simple anthropometric measurements such as BMI, waist-to-hip ratio and WC are cheaper and less time consuming. Browning et al. [29] compared in a cross-sectional study the relationship between visceral and total abdominal adipose tissue measurements obtained with MRI, BMI, WC, BIA and DXA. They found that men have more visceral abdominal fat than women. None of the simpler techniques like BMI or WC measurements showed strong correlations with visceral abdominal fat measured by MRI. Nevertheless, measurements of WC, BIA or DXA showed similar and strong correlations with total abdominal tissue and may be useful in large-scale surveys. Reine- 
hr and Wunsch [30] detected in their study with 29 obese children that WC, ultrasonographic measurement of intra-abdominal fat mass and BMI-SDS are significantly related to cardiovascular risk factors.

Another anthropometric method to determine intraabdominal fat in adults is the direct measurement of the abdominal diameter [31]. Sagittal abdominal diameter is a solid anthropometric measurement and can be a useful alternative to predict visceral fat in epidemiological studies in adults [31, 32], but there are only few publications available concerning children [33]. In a cross-sectional study with 964 children (aged 5-17 years), sagittal abdominal diameter was a reliable indicator of visceral obesity in Arab children [33]. A study of 144 Swedish children revealed a positive correlation between BMI and sagittal abdominal diameter, which was as strong as the correlation between BMI and WC [34].

In the present study we observed in boys and girls that obesity defined by either a BMI $\geq 97$ th or a WC $\geq 97$ th percentile was associated with hypertension and dyslipidemia. Similar results have also been reported by others [35]. There were differences in the strength of the relationship for individual risk factors. A WC $\geq 97$ th percentile was associated with higher cholesterol, triglyceride and lower HDL values, while a BMI $\geq 97$ th percentile was associated with higher values of systolic and diastolic blood pressure. In boys, a BMI $\geq 97$ th percentile was associated with high systolic blood pressure and high LDL values, while a WC $\geq 97$ th percentile was associated more strongly with high cholesterol values. In girls, a BMI $\geq 97$ th percentile was associated with increased systolic and diastolic blood pressure, cholesterol, triglyceride and lower HDL values compared to a $\mathrm{WC} \geq 97$ th percentile. This suggests that adolescent girls have more total fat mass than boys. Adolescent boys may have more visceral abdominal fat than total abdominal adipose tissue. Visceral fat is more closely correlated with metabolic risk than total fat [36]. These results confirm several studies which reported that sex differences in body fat distribution are amplified with maturation, especially from late puberty to early adulthood $[36,37]$. They also report that girls have less waist fat and more hip fat than boys. This suggests that WC measurement may be more useful in boys than in girls [38].

\section{Conclusion}

Youths with high BMI-SDS or high WC-SDS were more likely to have abnormal lipid profiles and elevated systolic and diastolic blood pressure than normal- weight youths. These findings demonstrate that BMISDS and WC-SDS are useful anthropometric measurements to identify children with higher cardiovascular risk factors. Both of the anthropometric measurements may be useful in large-scale surveys of youths as they are less time consuming, less invasive and less expensive than other screening tools (CT, DXA or BIA), and may be helpful to identify children who are at risk for CVD. However, there is no clear advantage of WC or the combination of BMI plus WC over BMI measurements alone.

\section{Limitations}

Limitations of the present study might be that elevated blood pressure could be white coat hypertension and that triglyceride measurements may not always be fasting in outpatients. This study has a focus on the at-risk group of overweight/obese youths. Different results may be found in primarily normal-weight subjects. In this analysis, the Tanner stage was not document in all children and adolescents, so subgroup analysis could not be performed. If this had been done, perhaps we would have come to another picture. Due to privacy restrictions it could be that there is a very small percentage of different ethnicities included in the study. In the European center we included only Caucasian patients.

\section{Acknowledgments}

The APV initiative is supported by grants from the German Federal Ministry of Education and Research (BMBF; Kompetenznetz Adipositas FKZ 01GI1130), the German Federal Center for Health Education (BZgA) and the European Foundation for the Study of Diabetes Type 2 (EFDS). We thank Angelika Schaffrath-Rosario (RKI, Berlin) for providing KiGGS reference data and Esther Molz (medical information specialist, Ulm) for data analysis. We thank all patients, their parents and care institutions contributing data to the APV initiative: Amrum Satteldüne Kinder-Reha, Augsburg Bunter Kreis, Bad Bodenteich Moby Dick Seeparkklinik, Bad Fallingbostel Gesundheitszentrum, Bad Frankenhausen KinderReha, Bad Hersfeld Kinderklinik, Bad Kösen Kinder-Reha, Bad Kreuznach Viktoriastift, Bad Lippspringe, Bad Mergentheim Kinderklinik, Bad Neuenahr - DRK Institutsambulanz, Bad Orb Spessartklinik - Kinder-Reha, Bad Rothenfelde Kinder-Reha, Bad Salzungen Reha-Klinik Charlottenhall, Bad Segeberg/Neumünster junior marvelesse, Bensheim Ernährungspraxis, Berchtesgaden CJD, Berchtesgaden Klinik Schönsicht Kinder-Reha, Berlin Charite Kinderklinik, Berlin Pfundskinder, Berlin DRK Moby Dick, Berlin Lichtenberg Kinderklinik, Berlin Vivantes Beh. Zentrum SPZ, Berlin Jugendrotkreuz (JRK), Bischofswiesen/Strub, INSULA, 
Blaubeuren Ernährungspraxis, Böblingen Kinderarztpraxis, Bonn Ernährungspraxis KIDS Schulung, Braunschweig ernährungsmed. Zentrum, Bregenz - Landeskrankenhaus Kinderklinik, Bremen Zentralkrankenhaus Kinderklinik, Bremen-Nord Kinderklinik, Bruchweiler Kinder-Reha, Brügge, Fördekids, Buchholz Ernährungsberatung, Bühl - Praxis Ernährungsberatung, Darmstadt Kinderklinik, Datteln Vestische Kinderklinik, Delmenhorster Kinderklinik, Detmold Kinderklinik, Dieburg Ernährungsberatung KIDS Schulung, Dinslaken Kinderklinik, Dornbirn Kinderklinik, Dorsten St. Elisabethkrhs., Dresden Moby Dick, Düren Gesundheitsamt, Düren sozialpäd. Zentrum Marienhospital, Düsseldorf Ernährungsberatung 'richtig essen', Düsseldorf Ernährungspraxis 'iss gut', Eppingen Kinderarztpraxis Schulze, Erlangen UniKinderklinik, Eschede Adipositastraining KIDS, Ettenheim Kinderarztpraxis, Euskirchen Kinderarztpraxis, Feldberg ITZ CaritasHaus, Feldkirch Landeskrankenhaus Kinderklinik, Flensburg Fördekids, Frankfurt Päd. Endokrinologie, Freiburg - Fitoc, Freiburg Uni-Kinderklinik, Friedrichsdorf Ernährungspraxis, Fürth Kinderklinik, Gaissach Fachklinik Deutsche Rentenversicherung Bayern-Süd, Garz Fachklinik CJD, Gauting-Kinderarztpraxis, Gelnhausen Ernährungsberatung, Giffers-Ausbildungszentrum Guglera, Gittelde am Harz - Ernährungsberatung, Gotha Helios Kinderklinik, Göttingen Uni-Kinderklinik, Göttingen, KIDS Schulungsprogramm, Gröbenzell Ernährungsberatung, Hagen Allgemeines Krankenhaus, Hagen Kinderarztpraxis, Hagen Kinderklinik, Hamburg Moby Dick Partner Konopka, Hamburg Moby Dick, Hamburg Rallye Energy, Hamburg Wilhelmstift, Hamburg-Sprungbrett, Hannover BKK Essanelle, Hannover Kinderklinik Bult, Hassfurt Adipositasschulung Hassberge, Herdecke Kinderklinik, Herne Praxis Ernährungsmedizin, Herrenberg Ernährungsberatung, Hirschberg Praxis Maurer, Homburg CJD, Homburg Uni-Kinderklinik, Kassel Kinderarztpraxis, Kiel städt. Krankenhaus Fördekids, Köln - Amsterdamerstrasse, Power Pänz, Köln - Prävention UniReha GmbH, Köln MeLo KIDS Schulungsprogramm, Köln Netzwerk Gesundheit, Deutsche Sporthochschule Köln, Kölpinsee, Seebad Klaus Störtebecker Kinder-Reha, Korbach Ernährungsberatung, Kreischa Klinikum Bavaria Zscheckwitz, Leipzig Sportmedizin, Leipzig Uni-Kinderklinik, Lindau Forum Adipositas, Lindenberg/Lindau Adipositasschulung, Lingen Bonifatius-Hospital, Lörrach Kinderklinik VPS, Lübeck UniKinderklinik, Luhe Ernährungsberatung/LuheVitalConcept, Mag- deburg - städtische Kinderklinik, Magdeburg Sportprogramm, Magdeburg Uni-Kinderklinik, Mahlow Ernährungspraxis, Menden BIG, Mönchengladbach städt. Kinderklinik, Mühlhausen Präventionspraxis, München Adieupositas, Münster Arztpraxis, Munster Ernährungs- und Bewegungsschulung für K\&J, Murnau KinderReha, Nagold Ernährungsberatung, Neumünster Präventionszentrum, Neunkirchen Kinderklinik, Neuss Lukaskrankenhaus, Niederkassel Kinderarztpraxis, Norden-Klinik Nordendeich, Nürnberg PEP, Oberhausen Adipositaszentrum, Oberhausen EKO Kinderklinik, Oberstaufen Ernährungsmedizin, Oberstenfeld Ernährungspraxis, Oldenburg Kids-Schulungsprogramm, Oldendorf Ernährungspraxis KiloKids, Osnabrück Kinderhospital, Overath KIDS-Schulungsprogramm, Oy-Mittelberg Reha, Paderborn Ernährungspraxis Kinderleicht, Passau Kinderklinik, Pforzheim Adipositas Training, Pocking Kinderarztpraxis, Pönitz FiFaFu KIDS-Programm, Poppenricht Ernährungsberatung, Potsdam Patienten Trainings Zentrum, Ravensburg Ernährung und Diät, Ravensburg Oberschwabenklinik Kinderklinik, Reiskirchen Ernährungspraxis, Rendsburg Villa Schwensen Praxisgemeinschaft KJPP, Ronneburg Ernährungsberatung, Rosenheim Lufti-Team, Rottweil Kinder-Leicht, Rüsselsheim Gesundheits- und Pflegezentrum, Saalfeld Kinderklinik, Saarbrücken Moby Dick, Salzburg Kinderklinik, Salzburg Uni-Kinderklinik, Salzgitter Kinderklinik, Scheidegg Prinzregent Luitpold Reha, Schliengen Ernährungsberatung, Schliengen Erwachsene, Seebad Heringsdorf - Kinder-Reha, Senden Ernährungsberatung, Siegburg KIDS Schulungsprogramm, Siegen DRK Kinderklinik, Simonswald Klinik Eichhof, Solingen Ernährungsberatung, Sonneberg KIDS Ernährungspraxis, St. Augustin Kinderklinik, St. Gallen Ostschweiz Kinderklinik, St. Pölten Landesklinikum Kinderklinik, Straubing Praxis, Tholey/SPZ Neunkirchen, Tübingen Universitäts-Kinderklinik, Ulm UniKinderklinik, Untergruppenbach Ernährungsberatung, Viersen Kinderklinik Nikolaus, Villingen-Schwenningen Kinderarztpraxis, Waldbröl Gemeinschaftspraxis, Waltrop Ernährungsberatung, Wangen Kinder-Rehaklinik, Westerland/Sylt, Haus Quickborn, Westerland/Sylt-Kinder-Reha, Wien Uni-Kinderklinik, Wiesbaden DKD Kinderklinik, Wiesmoor KIDS Schulungsprogramm, Windach Psychosomatik - Sportverein Triathlon, Würzburg ambulantes Schulungszentrum, Wustrow Ostseebad Fischland, Wyk auf Föhr - AOK Kinderkurheim, Zorneding Ernährungsberatung, and Zwickau - Praxis Ernährungsberatung.

\section{References}

1 Lobstein T, Frelut M-L: Prevalence of overweight among children in Europe. Obes Rev 2003;4:195-200.

-2 Ebbeling C, Pawlak D, Ludwig D: Childhood obesity: public-health crisis, common sense cure. Lancet 2002;360:473-482.

$\checkmark 3$ Blüher S, Meigen C, Gausche R, Keller E, Pfaffle R, Sabin M, et al: Age-specific stabilization in obesity prevalence in German children: a cross-sectional study from 1999 to 2008. Int J Pediatr Obes 2011;6:e199e206.

4 Basen-Engquist K, Chang M: Obesity and cancer: recent review and evidence. Curr Oncol Rep 2011;13:71-76. $\checkmark 5$ Lawson ML, Kirk S, Mitchell T, Chen MK, Loux TJ, Daniels SR, et al: One-year outcomes of Roux-en-Y gastric bypass for morbidly obese adolescents: a multicenter study from the Pediatric Bariatric Study Group. J Pediatr Surg 2006;41:137-143, discussion 137-143.

6 Elkiran O, Yilmaz E, Koc M, Kamanli A, Ustundag $\mathrm{B}$, Ilhan $\mathrm{N}$ : The association between intima media thickness, central obesity and diastolic blood pressure in obese and overweight children: a cross-sectional school-based study. Int J Cardiol 2013;165: 528-532.
7 Flechtner-Mors M, Thamm M, Wiegand S, Reinehr T, Schwab KO, Kiess W, et al: Comorbidities related to BMI category in children and adolescents: German/Austrian/ Swiss Obesity register APV compared to the German KiGGS Study. Horm Res Paediatr 2012;77:19-26.

$>8$ I'Allemand D, Wiegand S, Reinehr T, Müller J, Wabitsch M, Widhalm K, et al: Cardiovascular risk in 26,008 European overweight children as established by a multicenter database. Obesity (Silver Spring) 2008;16:1672-1679.

9 Phillips LK, Prins JB: The link between abdominal obesity and the metabolic syndrome. Curr Hypertens Rep 2008;10:156-164.
BMI or WC as a Predictor for

Hypertension and Dyslipidemia
Horm Res Paediatr 2013;80:170-178 DOI: 10.1159/000354224 
10 Denney-Wilson E, Hardy LL, Dobbins T, Okely AD, Baur LA: Body mass index, waist circumference, and chronic disease risk factors in Australian adolescents. Arch Pediatr Adolesc Med 2008;162:566-573.

11 Deutsche Gesellschaft für Ernährung e.V. http://www.dge.de.

-12 Emerging Risk Factor Collaboration, Wormser D, Kaptoge S, Di Angelantonio E, Wood AM, Pennells L, Thompson A, et al: Separate and combined associations of body-mass index and abdominal adiposity with cardiovascular disease: collaborative analysis of 58 prospective studies. Lancet 2011;377:1085-1095.

13 Yusuf S, Hawken S, Ounpuu S, Bautista L, Franzosi MG, Commerford P, et al: Obesity and the risk of myocardial infarction in 27,000 participants from 52 countries: a case-control study. Lancet 2005;366:1640-1649.

14 Reilly JJ, Kelly J, Wilson DC: Accuracy of simple clinical and epidemiological definitions of childhood obesity: systematic review and evidence appraisal. Obes Rev 2010;11: 645-655.

15 Lee S, Bacha F, Arslanian SA: Waist circumference, blood pressure, and lipid components of the metabolic syndrome. J Pediatr 2006;149:809-816.

16 Bekkers MB, Brunekreef B, Koppelman GH, Kerkhof M, de Jongste JC, Smit HA, et al: BMI and waist circumference; cross-sectional and prospective associations with blood pressure and cholesterol in 12-year-olds. PLoS One 2012; 7:e51801.

17 Kromeyer-Hauschild K, Dortschy R, Stolzenberg H, Neuhauser H, Rosario AS: Nationally representative waist circumference percentiles in German adolescents aged 11.0-18.0 years. Int J Pediatr Obes 2011;6:e129-e137.

18 Stolzenberg H, Kahl H, Bergmann KE: Body measurements of children and adolescents in Germany. Results of the German Health Interview and Examination Survey for Children and Adolescents (KiGGS) (in German). Bundesgesundheitsblatt Gesundheitsforschung Gesundheitsschutz 2007;50:659-669.

19 Rosario AS, Kurth BM, Stolzenberg H, Ellert U, Neuhauser $\mathrm{H}$ : Body mass index percentiles for children and adolescents in Germany based on a nationally representative sample (KiGGS 2003-2006). Eur J Clin Nutr 2010;64:341-349.
20 Neuhauser HK, Thamm M, Ellert U, Hense HW, Rosario AS: Blood pressure percentiles by age and height from nonoverweight children and adolescents in Germany. Pediatrics 2011;127:e978-e988.

21 Kavey RE, Daniels SR, Lauer RM, Atkins DL, Hayman LL, Taubert K: American Heart Association guidelines for primary prevention of atherosclerotic cardiovascular disease beginning in childhood. Circulation 2003;107: 1562-1566.

22 Holm S: A simple sequentially rejective multiple test procedure. Scand J Stat 1979;6:6570.

23 Plachta-Danielzik S, Landsberg B, Johannsen M, Lange D, Muller MJ: Association of different obesity indices with blood pressure and blood lipids in children and adolescents. Br J Nutr 2008;100:208-218.

24 Meng L, Luo N, Mi J: Impacts of types and degree of obesity on non-alcoholic fatty liver disease and related dyslipidemia in Chinese school-age children? Biomed Environ Sci 2011;24:22-30.

25 Browning LM, Mugridge O, Chatfield MD, Dixon AK, Aitken SW, Joubert I, et al: Validity of a new abdominal bioelectrical impedance device to measure abdominal and visceral fat: comparison with MRI. Obesity (Silver Spring) 2010;18:2385-2391.

26 Taylor RW, Jones IE, Williams SM, Goulding A: Evaluation of waist circumference, waistto-hip ratio, and the conicity index as screening tools for high trunk fat mass, as measured by dual-energy $\mathrm{X}$-ray absorptiometry, in children aged 3-19 y. Am J Clin Nutr 2000;72: 490-495.

27 Moreno LA, Pineda I, Rodriguez G, Fleta J, Sarria A, Bueno M: Waist circumference for the screening of the metabolic syndrome in children. Acta Paediatr 2002;91:1307-1312.

28 Berker D, Koparal S, Isik S, Pasaoglu L, Aydin Y, Erol K, et al: Compatibility of different methods for the measurement of visceral fat in different body mass index strata. Diagn Interv Radiol 2010;16:99-105.
29 Browning LM, Mugridge O, Dixon AK, Aitken SW, Prentice AM, Jebb SA: Measuring abdominal adipose tissue: comparison of simpler methods with MRI. Obes Facts 2011;4: 9-15.

30 Reinehr T, Wunsch R: Relationships between cardiovascular risk profile, ultrasonographic measurement of intra-abdominal adipose tissue, and waist circumference in obese children. Clin Nutr 2010;29:24-30.

31 Pimentel GD, Moreto F, Takahashi MM, Portero-McLellan KC, Burini RC: Sagital abdominal diameter, but not waist circumference is strongly associated with glycemia, triacilglycerols and HDL-C levels in overweight adults. Nutr Hosp 2011;26:1125-1129.

-32 Zamboni M, Turcato E, Armellini F, Kahn HS, Zivelonghi A, Santana H, et al: Sagittal abdominal diameter as a practical predictor of visceral fat. Int J Obes Relat Metab Disord 1998;22:655-660.

33 Larsson C, Hernell O, Lind T: Moderately elevated body mass index is associated with metabolic variables and cardiovascular risk factors in Swedish children. Acta Paediatr 2011;100:102-108.

34 Al-Daghri N, Alokail M, Al-Attas O, Sabico S, Kumar S: Establishing abdominal height cutoffs and their association with conventional indices of obesity among Arab children and adolescents. Ann Saudi Med 2010;30:209-214.

35 Holl RW, Hoffmeister U, Thamm M, Stachow R, Keller KM, L'Allemand D, et al: Does obesity lead to a specific lipid disorder? Analysis from the German/Austrian/Swiss APV registry. Int J Pediatr Obes 2011;6(suppl 1):53-58.

36 Moreno LA, Mesana MI, Gonzalez-Gross M, Gil CM, Ortega FB, Fleta J, et al: Body fat distribution reference standards in Spanish adolescents: the AVENA Study. Int J Obes (Lond) 2007;31:1798-1805.

37 Taylor RW, Grant AM, Williams SM, Goulding A: Sex differences in regional body fat distribution from pre- to postpuberty. Obesity (Silver Spring) 2010;18:1410-1416.

- 38 Nguyen N, Magno C, Lane K, Hinojosa M, Lane J: Association of hypertension, diabetes, dyslipidemia, and metabolic syndrome with obesity: findings from the National Health and Nutrition Examination Survey, 1999 to 2004. J Am Coll Surg 2008;207:928-934. 